\title{
PENGARUH WAKTU FORTIFIKASI VITAMIN B12 (SIANOKOBALAMIN) DAN VITAMIN D3 (KALSIFEROL) TERHADAP MUTU GIZI KEFIR SUSU KAMBING
}

\author{
Ocka Febrian Mumpuni, Reza Achmad Maulana, Fitriyono Ayustaningwarno, Binar Panunggal, \\ Gemala Anjani*
}

\begin{abstract}
Departemen Ilmu Gizi, Fakultas Kedokteran, Universitas Diponegoro. Jl. Prof. Sudarto SH, Tembalang, Semarang, Jawa Tengah 50275, Indonesia "Penulis Penanggungjawab: E-mail: gemaanjani@gmail.com
\end{abstract}

\begin{abstract}
Background: Kefir becomes the proper nutrient fortification medium because it has natural encapsulation substance that is kefiran. The addition of vitamin B12 and vitamin D3 to prevent vitamin B12 and D3 deficiency in the state of insulin resistance improves the nutritional quality of goat milk kefir.

Objectives: To analyze the effect of vitamin B12, vitamin D3 fortification time on goats milk kefir nutritional quality.

Methods: This study with Quasi Experimental Research with randomized design. The study used fortified vitamins B12 and D3 with fortified additions at the 0th, 6th, 12th, 18th and 24th hours, and 1st control group $(t=5$.

Results Fortification of vitamin B12 and D3 in goat milk kefir between control group and treatment group was significantly different in vitamin D3 $(p=0.000)$ protein content $(p=0.030)$, and fiber content $(p=0.000), p H$ concentration ( $p=0.008)$, concentration of Vitamin B12 $(p=0.165)$, viscosity $(p=0.646)$ and fat $(p=0.265)$

Conclusion: Fortification of vitamin B12 and D3 in goat milk kefir obtained optimum levels of vitamin B12 and D3 fortification in the 12th time.
\end{abstract}

Keywords : ettawa goat milk; goat milk kefir; insulin resistance; fortification; vitamin B12 and vitamin D3

\section{ABSTRAK}

Latar belakang: Kefir menjadi media fortifikasi zat gizi yang tepat karena memiliki zat enkapsulasi alami yaitu kefiran. Penambahan vitamin B12 dan vitamin D3 untuk mencegah kekurangan vitamin B12 dan D3 pada keadaan resistensi insulin serta meningkatkan mutu gizi kefir susu kambing.

Tujuan: Mengetahui adanya pengaruh waktu fortifikasi vitamin B12, vitamin D3 pada mutu gizi kefir susu kambing.

Metode: Penelitian ini menggunakan fortifikan vitamin B12 dan D3 dengan penambahan fortifikan pada jam ke-0, ke6, ke-12, ke-18 dan ke-24.

Hasil: Fortifikasi vitamin B12 dan D3 pada kefir susu kambing antara kelompok kontrol dengan kelompok perlakuan signifikan beda nyata pada kadar vitamin $D 3(p=0,000)$ kadar protein $(p=0,030)$, dan kadar serat $(p=0,000)$, diikuti hasil konsentrasi $p H(p=0,008)$, diikuti oleh kadar konsentrasi vitamin $B 12(p=0,165)$, viskositas $(p=0,646)$ dan lemak $(p=0,265)$

Simpulan: Fortifikasi vitamin B12 dan D3 pada kefir susu kambing mendapatkan tingkat kadar optimum terjadi pada fortifikasi vitamin B12 dan D3 pada kelompok perlakuan jam ke-12.

Kata Kunci : susu kambing ettawa; kefir susu kambing; resistensi insulin; fortifikasi; vitamin B12 dan vitamin D3

\section{PENDAHULUAN}

Susu kambing ettawa merupakan hasil susu yang berasal dari kambing peranakan ettawa. Dalam satu hari kambing ettawa dapat menghasilkan susu sebanyak 3 liter. Kambing ettawa memiliki butiran lemak yang lembut, halus dan lebih kecil daripada butiran lemak susu sapi. Susu kambing seperti susu yang berasal dari sumber hewan lainya merupakan campuran yang kompleks, yaitu emulsi lemak dalam air. $^{1}$

Globula lemak susu kambing memiliki ukuran lebih kecil sehingga lemak susu kambing lebih mudah dicerna dan dapat di konsumsi orang yang mengalami alergi terhadap susu sapi, atau untuk orang yang mengalami gangguan pencernaan. Komponen utama penyusun susu kambing seperti laktosa, lemak, senyawa nitrogen, dan mineral memiliki kemiripan dengan susu sapi. Susu kambing memiliki ukuran rata-rata butiran lemak sebesar 2 mikrometer, lebih kecil dari pada ukuran butiran lemak susu sapi yang mencapai 2,5-3,5 mikrometer. Ukuran butiran lemak yang lebih kecil ini membuat lemak susu kambing lebih tersebar dan homogen sehingga lebih mudah dicerna oleh sistem pencernaan manusia. ${ }^{2}$ Tekstur lemak yang lembut dan halus mengakibatkan butiran lemak yang terkandung dalam susu kambing ettawa menjadi lebih mudah dicerna oleh tubuh. ${ }^{3}$

Susu kambing memiliki kandungan vitamin dalam jumlah yang cukup, terkecuali pada kandungan vitamin C, D (kalsiferol), piridoksin, asam folat dan sianokobalamin. ${ }^{4}$ Susu kambing tidak 
memiliki pigmen karoten karena kandungan vitamin A pada susu kambing tidak tersusun sebagai pigmen karotenoid sehingga susu kambing lebih berwarna putih daripada susu sapi. Dengan adanya pigmen karotenoid pada susu sapi maka susu sapi lebih berwarna kuning dibandingkan dengan susu kambing. Fortifikasi vitamin B12 dan vitamin D3 pada kefir susu kambing dipilih dikarenakan rendahnya kandungan vitamin B12 sebesar 0,065 mcg dan vitamin D3 sebesar $0,11 \mathrm{mcg}$ pada susu kambing. ${ }^{5}$

Salah satu produk olahan dari susu kambing ettawa adalah kefir. ${ }^{6}$ Kefir merupakan produk olahan susu yang difermentasi dengan kefir grains terdiri dari berbagai jenis bakteri asam laktat dan ragi. Kefir berupa minuman sejenis susu fermentasi yang terbuat dari bakteri hidup yang mudah diserap dan memiliki banyak manfaat. Dalam pembuatan kefir menggunakan starter biji kefir (kefir grains) dan bakteri asam laktat yaitu Lactobacillus acidophilus dan Saccharomyces. Kefir mengandung zat alami yang disebut Kefiran. Kefiran merupakan zat enkapsulasi alami yang berguna untuk proses enkapsulasi zat gizi dalam proses fortifikasi. Kefiran bekerja mengikat campuran zat yang terdapat dalam minuman kefir. ${ }^{7}$

Proses enkapsulasi menggunakan kefiran bertujuan untuk menjaga zat yang ditambahkan pada kefir tidak mengalami pengurangan kadar pada saat penyimpanan. Kefiran sering digunakan untuk mendukung proses penambahan zat atau fortifikasi zat gizi pada kefir susu kambing. Kefir dibuat dengan mencampurkan susu dan starter biji kefir yang dibiarkan diurai oleh bakteri yang sering disebut dengan proses fermentasi. Kefir biasanya terbuat dari susu sapi, susu kambing atau susu kambing jenis peranakan ettawa. ${ }^{8}$ Dalam upaya meningkatkan mutu gizi kefir susu kambing dengan melakukan penambahan zat gizi tertentu yang dapat berguna untuk kesehatan dan mencegah terjadinya defisiensi zat gizi. Penambahan zat gizi produk makanan atau minuman seperti kefir susu kambing sering disebut dengan proses fortifikasi. ${ }^{9}$

Fortifikasi pada makanan atau minuman merupakan salah satu cara untuk meningkatkan kandungan zat gizi melalui penambahan satu atau lebih zat gizi esensial (fortifikan) pada makanan atau minuman yang biasa dikonsumsi. Susu merupakan media fortifikasi yang baik karena mempunyai nilai bioavailabilitas dan nilai gizi tinggi serta banyak dikonsumsi oleh masyarakat luas. Susu kambing memiliki kandungan protein sebesar 3,49\% dan lemak 5,23\% yang lebih tinggi dibandingkan dengan susu sapi. ${ }^{9}$ Fortifikasi vitamin B12 dan D3 pada kefir susu kambing berguna untuk meningkatkan mutu gizi dari kefir susu kambing. ${ }^{10}$
Fortifikasi vitamin B12 dan D3 dipilih karena adanya deplesi atau pengurangan kadar vitamin B12 dan vitamin D pada saat tubuh mengalami resistensi insulin. Resistensi insulin adalah ketidakmampuan tubuh dalam penyerapan glukosa darah yang menyebabkan peningkatan kadar glukosa darah. Resistensi insulin menyebabkan terjadinya penyakit Diabetes Mellitus tipe 2 (DM 2). ${ }^{11}$ Pada pengobatan DM 2 menggunakan metformin memiliki efek yang dapat mengurangi (deplesi) kadar vitamin B12 dalam tubuh. Hal ini menyebabkan vitamin B12 berada pada fase borderline yaitu keadaan dimana vitamin B12 berada pada kadar minimal atau dibawah normal. ${ }^{12}$

Tidak hanya pada vitamin B12, deplesi vitamin D terjadi pada keaadan tubuh mengalami resistensi insulin. Kekurangan vitamin D menimbulkan efek terjadinya masalah sindrom metabolik seperti gangguan muskuloskeletal, kanker, sklerosis, penyakit kardiovaskular dan diabetes mellitus. Hal ini terjadi karena penyakit diabetes mellitus disebabkan oleh keadaan tubuh yang mengalami resistensi insulin. Dalam menghindari terjadinya resitensi insulin dan penyakit sindrom metabolik serta mencegah tidak tercukupinya kedua vitamin tersebut dalam tubuh, perlu menjaga kadar vitamin B12 dan vitamin D3 agar tubuh tidak dalam keadaan kurang. ${ }^{13-16}$

Dengan melakukan fortifikasi pada produk kefir susu kambing diharapkan mampu menanggulangi dan mencegah kekurangan vitamin B12 dan D3 serta diharapkan mampu menjaga konsistensi kadar zat fortifikan serta mencegah terjadinya defisit vitamin B12 dan vitamin D3 pada produk kefir susu kambing. Tujuan paper ini adalah untuk mengetahui adanya pengaruh waktu fortifikasi terhadap kadar vitamin B12, vitamin D3 dan mutu gizi kefir susu kambing.

\section{METODE}

Penelitian ini menggunakan fortifikasi vitamin B12 dan vitamin D3 dengan penambahan fortifikan pada jam ke-0, fortifikasi vitamin B12 dengan penambahan fortifikan pada jam ke-0, ke-6, ke-12, ke-18 dan ke-24, serta 1 kelompok kontrol (tanpa fortifikasi). Setiap kelompok dilakukan 3 kali pengulangan sehingga diperoleh 18 satuan percobaan dilakukan analisis meliputi analisis konsentrasi kadar fortifikan vitamin B12 dan D3 serta analisis konsentrasi kadar Lemak, Protein, Serat kasar, $\mathrm{pH}$ dan Viskositas. Seluruh analisa sampel dilakukan setelah 24 jam inkubasi.

Subjek penelitian ini adalah kefir susu kambing yang terbuat dari proses fermentasi susu kambing sebagai bahan utama dengan starter biji kefir (kefir grains) dan bakteri asam laktat 
(Lactobacillus acidophilus dan Saccharomyces), dengan penambahan zat fortifikan berupa vitamin B12 (sianokobalamin) dan vitamin D3 (kalsiferol). Susu kambing yang digunakan adalah susu kambing peranakan ettawa yang didapatkan dari Omah Kefir Ungaran. Starter biji kefir (kefir grains) juga didapat dari Omah Kefir Ungaran. Zat fortifikan vitamin B12 (sianokobalamin) didapat dari Vitamin Kita Store Indonesia. Zat fortifikan vitamin D3 (kalsiferol) didapat dari Mega Store Indonesia. Kelompok kontrol menggunakan kefir susu kambing tanpa penambahan vitamin B12 dan vitamin D3.

Tahapan penelitian diawali dengan pembuatan kefir dengan menyiapkan susu kambing sebanyak 1liter yang telah dipanaskan hingga suhu $70^{\circ} \mathrm{C}$ selama 30 menit. Kemudian ditambahkan starter biji kefir (kefir grains) sebanyak 50g di inkubasi selama 24 jam dengan suhu ruang $24-25^{\circ} \mathrm{C}$ terjadi proses fermentasi menjadi kefir susu kambing. ${ }^{17}$ Kemudian dilakukan penambahan zat fortifikan vitamin B12 sebanyak $20 \mathrm{mcg} / 100 \mathrm{ml}$ dan vitamin D3 sebanyak $42 \mathrm{IU} / 100 \mathrm{ml}^{18,19}$ Konsentrasi vitamin B12 dan D3 seluruh sampel penelitian di uji menggunakan metode spektrofotometri (Shimadzu) dengan terlebih dahulu melarutkan sampel pada campuran kloroform:methanol =1:9. Sampel tersebut dianalisis dengan spectrometer pada panjang gelombang 264 nm untuk vitamin D3. ${ }^{20}$ Sedangkan uji vitamin B12 dilakukan pada panjang gelombang $530 \mathrm{~nm}$. Kadar lemak dianalisa dengan menggunakan metode Babcock, kadar protein menggunakan metode Bradford, nilai $\mathrm{pH}$ diukur menggunakan $\mathrm{pH}$ meter
(La Motte), kadar serat kasar diukur dengan metode gravimetri dan viskositas sampel diuji dengan metode Ostwald.

Pengolahan data menggunakan software statistik. Analisis pengaruh fortifikasi vitamin B12 dan vitamin D3 terhadap mutu gizi kefir susu kambing meliputi kadar vitamin B12 dan vitamin D3 serta kadar lemak, protein, serat, $\mathrm{pH}$, dan viskositas menggunakan uji statistika One Way Annova dilanjutkan dengan uji Post hoc Tukey Duncan Alpha untuk melihat perbedaan antara kefir kontrol dengan kefir yang diberi perlakuan.

\section{HASIL}

Kadar vitamin D3 antara kelompok kontrol dan kelompok perlakuan (0 jam, 6 jam, 12 jam, 18 jam dan 24 jam) berbeda nyata $(p=0,000)$ (Tabel $1)$.

Tabel 1. Konsentrasi D3 (IU)

\begin{tabular}{llccc} 
Sampel & Mean \pm SD & Minimal & Maksimal & $\boldsymbol{p}$ \\
\hline Kontrol & $43,11 \pm 0,20^{\mathrm{a}}$ & 42,90 & 43,29 & 0,000 \\
0 jam & $71,05 \pm 2,59^{\mathrm{c}}$ & 69,03 & 73,97 & \\
6 jam & $85,55 \pm 0,02^{\mathrm{d}}$ & 85,52 & 85,56 & \\
12 jam & $93,14 \pm 0,86^{\mathrm{e}}$ & 92,48 & 94,11 & \\
18 jam & $83,7 \pm 0,24^{\mathrm{d}}$ & 83,53 & 84,00 & \\
24 jam & $53,58 \pm 2,27^{\mathrm{b}}$ & 51,65 & 56,08 & \\
\hline
\end{tabular}

Keterangan : Angka yang diikuti huruf superscript berbeda (a, b, c, d,e) menunjukkan beda nyata

Tabel 2 juga menunjukkan konsentrasi vitamin B12 antara kelompok kontrol dan kelompok perlakuan (0 jam, 6 jam, 12 jam, 18 jam dan 24 jam) tidak berbeda nyata $(p=0.165)$.

Tabel 2. Konsentrasi Kadar Vitamin B12 (mcg)

\begin{tabular}{|c|c|c|c|c|}
\hline Sampel & Mean \pm SD & Minimal & Maksimal & $p$ \\
\hline Kontrol & $1115,83 \pm 198,20$ & 894,38 & 1276,56 & 0,165 \\
\hline 0 jam & $1207,92 \pm 8,96$ & 1198,44 & 1216,25 & \\
\hline $6 \mathrm{jam}$ & $1168,54 \pm 118,20$ & 1071,88 & 1300,31 & \\
\hline $12 \mathrm{jam}$ & $907,08 \pm 174,83$ & 722,81 & 1070,63 & \\
\hline 18 jam & $1078,33 \pm 145,32$ & 912,50 & 1183,44 & \\
\hline 24 jam & $985,83 \pm 125,40$ & 853,44 & 1102,81 & \\
\hline
\end{tabular}

Tabel 3. Viskositas $\left(\mathrm{cm} / \mathrm{s}^{2}\right)$

\begin{tabular}{|c|c|c|c|c|}
\hline Sampel & Mean \pm SD & Minimal & Maksimal & $p$ \\
\hline Kontrol & $0,1325 \pm 0,01029$ & 0,12 & 0,14 & 0.600 \\
\hline 0 jam & $0,1474 \pm 0,00445$ & 0,14 & 0,15 & \\
\hline $6 \mathrm{jam}$ & $0,1395 \pm 0,01952$ & 0,12 & 0,16 & \\
\hline $12 \mathrm{jam}$ & $0,1310 \pm 0,01436$ & 0,12 & 0,15 & \\
\hline 18 jam & $0,1295 \pm 0,01182$ & 0,12 & 0,14 & \\
\hline 24 jam & $0,1459 \pm 0,02727$ & 0,12 & 0,17 & \\
\hline
\end{tabular}

Viskositas antara kelompok kontrol dan kelompok perlakuan ( 0 jam, 6 jam, 12 jam, 18 jam dan 24 jam) tidak berbeda nyata $(p=0.646)$ (Tabel 3).
Kadar lemak kelompok kontrol dan kelompok perlakuan (0 jam, 6 jam, 12 jam, 18 jam dan 24 jam) tidak berbeda nyata $(p=0.265)$ (Tabel 4$)$. 
Tabel 4. Kadar Lemak (\%)

\begin{tabular}{lcccc}
\hline Sampel & Mean \pm SD & Minimal & Maksimal & $\boldsymbol{p}$ \\
\hline Kontrol & $8,47 \pm 0,40$ & 8,21 & 8,94 & 0,265 \\
0 jam & $7,20 \pm 0,16$ & 7,04 & 7,35 & \\
6 jam & $6,86 \pm 1,02$ & 5,68 & 7,47 & \\
12 jam & $6,91 \pm 1,66$ & 5,05 & 8,24 & \\
18 jam & $7,16 \pm 1,13$ & 5,98 & 8,23 & \\
24 jam & $6,59 \pm 0,23$ & 6,43 & 6,85 & \\
\hline
\end{tabular}

Kadar serat kelompok kontrol dan kelompok perlakuan (0 jam, 6 jam, 12 jam, 18 jam dan 24 jam) menunjukan beda nyata $(p=0.000)$ (Tabel 5).
Tabel 5. Kadar Serat (\%)

\begin{tabular}{llrcc}
\hline Sampel & Mean \pm SD & Minimal & Maksimal & $\boldsymbol{p}$ \\
\hline Kontrol & $23,30 \pm 1,57^{\mathrm{c}}$ & 22,25 & 25,10 & 0,000 \\
0 jam & $11,93 \pm 2,53^{\mathrm{ab}}$ & 9,20 & 14,20 & \\
6 jam & $13,80 \pm 1,97^{\mathrm{ab}}$ & 12,20 & 16,00 & \\
12 jam & $9,55 \pm 2,30^{\mathrm{a}}$ & 8,20 & 12,20 & \\
18 jam & $9,60 \pm 1,91^{\mathrm{a}}$ & 7,40 & 10,80 & \\
24 jam & $15,87 \pm 0,31^{\mathrm{b}}$ & 15,60 & 16,20 & \\
\hline \multicolumn{4}{l}{ Keterangan: Angka yang diikuti huruf superscript berbeda $(\mathrm{a}, \mathrm{b}, \mathrm{c})$} \\
\multicolumn{4}{l}{}
\end{tabular}

Kadar protein kelompok kontrol dan kelompok perlakuan ( 0 jam, 6 jam, 12 jam, 18 jam dan 24 jam) berbeda nyata $(p=0,030)$ (Tabel 6).

Tabel 6. Kadar Protein (\%)

\begin{tabular}{llccc}
\hline Sampel & Mean \pm SD & Minimal & Maksimal & $p$ \\
\hline Kontrol & $0,6215 \pm 0,07113^{\mathrm{a}}$ & 0,54 & 0,67 & 0,030 \\
0 jam & $0,7300 \pm 0,05629^{\mathrm{ab}}$ & 0,67 & 0,78 & \\
6 jam & $0,641 \pm 0,06949^{\mathrm{ab}}$ & 0,57 & 0,71 & \\
12 jam & $0,6520 \pm 0,07050^{\mathrm{ab}}$ & 0,58 & 0,73 & \\
18 jam & $0,7854 \pm 0,04521^{\mathrm{b}}$ & 0,75 & 0,84 & \\
24 jam & $0,7303 \pm 0,01887^{\mathrm{ab}}$ & 0,71 & 0,75 & \\
\hline
\end{tabular}

Keterangan: Angka yang diikuti huruf superscript berbeda $(a, b)$ menunjukkan beda nyata

$\mathrm{pH}$ kelompok kontrol dan kelompok perlakuan (0 jam, 6 jam, 12 jam, 18 jam dan 24 jam) tidak berbeda nyata $(p=0,800)$ (Tabel 7).

Tabel 7. pH

\begin{tabular}{llccc}
\hline Sampel & Mean \pm SD & Minimal & Maksimal & $\boldsymbol{p}$ \\
\hline Kontrol & $4,40 \pm 0,150^{\mathrm{a}}$ & 4,25 & 4,55 & 0,800 \\
0 jam & $4,32 \pm 0,176^{\mathrm{a}}$ & 4,15 & 4,50 & \\
6 jam & $4,55 \pm 0,05^{\mathrm{ab}}$ & 4,50 & 4,60 & \\
12 jam & $4,53 \pm 0,06^{\mathrm{ab}}$ & 4,50 & 4,60 & \\
18 jam & $4,53 \pm 0,12^{\mathrm{ab}}$ & 4,40 & 4,60 & \\
24 jam & $4,78 \pm 0,12^{\mathrm{b}}$ & 4,65 & 4,85 & \\
\hline
\end{tabular}

Keterangan: Angka yang diikuti huruf superscript berbeda (a, b) menunjukkan beda nyata

\section{PEMBAHASAN \\ Vitamin D3}

Fortifikasi vitamin D3 sangat dibutuhkan terutama pada kefir, yang hanya memiliki kandungan kandungan vitamin D3 sebesar 0,55 IU. ${ }^{5}$ Walaupun data pada Tabel 1 memperlihatkan bahwa kadar vitamin D3 pada kefir susu kambing ettawa dalam penelitian ini sebanyak 43,11 \pm 0,20 IU. Data juga menunjukkan terjadinya peningkatan kadar vitamin D3 pada kelompok perlakuan fortifikasi jam ke $0,6,12$ kemudian penurunan pada fortifikasi jam ke 18 dan 24. Hasil tersebut berbeda dengan penelitian sebelumnya yang menyatakan bahwa fortikasi pada jam ke 6 adalah waktu fortifikasi terbaik untuk vitamin D3 dalam media kefir. $^{21}$

Pada penelitian ini, digambarkan bagaimana kondisi ideal fortifikasi adalah pada jam ke 6 dan jam ke 18, yang ditunjukkan dengan kadar vitamin D3 total yang merupakan jumlah dari VD3 awal dan jumlah fortifikan. Sedangkan efek sinergistik fortifikasi ditunjukkan pada fortifikasi kefir jam ke 12. Pada jam fortifikasi jam ke 0, kadar vitamin D3 total belum maksimal dimungkinkan karena fortifikasi vitamin D3 dilakukan bersamaan dengan pembahan biji kefir, dimana semua mikroba dalam kefir berada pada fase pertumbuhan awal. Tabel 1 juga menunjukkan bahwa pada fortifikasi jam ke 24 memiliki nilai total vitamin D3 terendah, dimana pada saat ini proses inkubasi sudah berakhir.

Perbedaan total vitamin D3 pada berbagai waktu fortifikasi dimungkinkan karena mikroorganisme pada kefir adalah mikroorganisme heterogen yang terdiri atas bakteri dan khamir dengan aktivitas proteolisis dan lipolsis. Degradasi protein dapat mempengaruhi stabilitas konsentrasi vitamin D3 karena kemampuan pengikatan dengan $\beta$ - laktoglobulin A dan $\beta$-kasein. Sedangkan $\beta$ Laktoglobulin A and $\beta$-kasein banyak terdapat pada whey protein dan kasein susu kambing. ${ }^{22} \beta$ Laktoglobulin A and $\beta$-kasein terikat dengan ikatan yang kuat pada vitamin D3. Akan tetapi, selama proses fermentasi terjadi proses proteolisis yang mengubah $\beta$-Laktoglobulin A and $\beta$-kasein menjadi arginine dan glutamin. Sehingga keadaan tersebut berpengaruh terhadap stabilitas vitamin D3 dalam sistem. ${ }^{23,24}$

\section{Vitamin B12}

Berdasarkan data pada Tabel 2, Kelompok perlakuan fortikasi vitamin B12 pada jam ke 0, 6, 
12, 18 dan 24 menunjukkan perubahan total vitamin B12 dalam kisaran yang sama dan secara statistik tidak signifikan $(\mathrm{p}=0.165)$. Penelitian sebelumnya dengan susu kambing sejenis menyebutkan bahwa kadar vitamin B12 yang digunakan sudah memiliki kadar vitamin B 12 yang mencukupi kebutuhan yaitu 819.7 mcg. ${ }^{21}$ Dengan adanya proses fermentasi dengan mikroba kefir, kadar vitamin B12 meningkat pada kisaran 907,08-1207,92 mcg.

Fortifikasi vitamin B12 sebanyak $20 \mathrm{mcg} / 100$ ml susu kambing tidak efektif meningkatkan kadar vitamin B12 dalam kefir susu kambing. Hal ini dikarenakan kandungan vitamin B12 dalam kefir susu kambing sudah cukup tinggi.

Vitamin B12 merupakan vitamin yang berkaitan dengan aktifitas bakteri pada proses fermentasi. ${ }^{25}$ Selama proses fermentasi susu kambing menjadi kefir terjadi peningkatan kadar vitamin B12, asam folat dan pyridoxine karena biositesis bakteri fermentasi. ${ }^{26,27}$ Bakteri Propionibacterium shermani B369 Propionibacterium freudenreichi spp merupakan bakteri yang dapat memproduksi vitamin B12 selama proses fermentasi. ${ }^{28}$ Hal ini didukung penelitian lain yang menyebutkan bahwa aktifitas bakteri dan kefiran pada kefir susu kambing membantu mengikat dan meningkatkan konsentrasi kadar vitamin B12. ${ }^{17}$

\section{Viskositas}

Hasil penelitian ini menunjukkan bahwa terdapat perbedaan viskositas dan tekstur antara susu kambing dan kefir susu kambing. Secara diskriptif digambarkan bahwa kefir memiliki tekstur lebih kental dibandingkan susu kambing. Sedangkan viskositas kelompok kontrol dan kelompok perlakuan (0 jam, 6 jam, 12 jam, 18 jam dan 24 jam ) tidak menunjukkan hasil yang berbeda nyata $(\mathrm{p}=$ 0.6) (Tabel 3).

Nilai viskositas dipengaruhi oleh beberapa faktor termasuk diantaranya bakteri asam laktat, total padatan, kadar lemak, dan kadar protein didalam sistem kefir. ${ }^{29}$ Penelitian sebelumnya menyebutkan bahwa viskositas juga dipengaruhi oleh kandungan eksopolisakarida atau kefiran. Kefiran merupakan polisakarida utama yang diproduksi oleh mikroba pada kefir yang biasanya dihasilkan oleh Lactobacillus kefir atau Lactobacillus kefiranofaciens. Selain itu bakteri asam laktat berperan pada produksi polisakarida ekstraseluler yang berkontribusi pada tekstur produk-produk susu fermentasi. Bakteri asam laktat juga berperan pada penggumpalan protein oleh asam yang dihasilkan selama fermentasi. Sedangkan, aktivitas proteolitik pada proses fermentasi dapat menurunkan viskositas melalui mekanisme degradasi struktur protein. ${ }^{23,24}$

\section{Lemak}

Kadar lemak kelompok kontrol dan kelompok perlakuan (0 jam, 6 jam, 12 jam, 18 jam dan 24 jam ) menunjukkan hasil yang secara statistik tidak berbeda nyata ( $p=0,2650)$. Akan tetapi dari hasil penelitian menunjukkan bahwa penambahan vitamin B12 dan vitamin D3 menunjukan adanya penurunan kadar lemak (Tabel 4). Penurunan kadar lemak dimungkinkan oleh perkembangbiakan bakteri asam laktat (BAL) selama proses fermentasi. Aktivitas metabolisme enzim lipase dari bakteri asam laktat yang semakin banyak meningkatkan terjadinya peningkatan hidrolisis lemak menjadi asam-asam lemak. $^{30}$

\section{Serat}

Kadar serat kelompok kontrol dan kelompok perlakuan ( 0 jam, 6 jam, 12 jam, 18 jam dan 24 jam ) $(p=0,000)$ berbeda nyata. Hasil menunjukan adanya pengaruh penambahan vitamin B12 dan vitamin D3 terhadap kadar serat kefir susu kambing. Vitamin B12 diproduksi mikroba pada saat fermentasi kefir susu kambing, dan sebaliknya mikroba menggunakan serat sebagai asupan untuk membantu proses fermentasi kefir susu kambing. Hal tersebut menyebabkan terjadinya penurunan kadar serat pada kefir susu kambing secara signifikan. ${ }^{31}$

\section{Protein}

Tabel 6 menunjukkan bahwa waktu fortifikasi vitamin B12 dan vitamin D3 berpengaruh ( $p=$ 0,030) terhadap perubahan kadar protein. Selama proses fermentasi dengan penambahan berbagai mikroorganisme kefir, dimungkinkan adanya aktivitas proteolitik, dimana terjadi pemecahan protein kompleks menjadi asam-asam amino sederhana. Pada penelitian ini, didapatkan bahwa fortifikasi jam ke 6 dan ke 12 memperlihatkan peningkatan kadar protein, tetapi tidak dengan fortifikasi jam ke 0,18 dan 12. Hal ini dimungkinkan bahwa pada perlakuan jam ke 6 dan 12 , penambahan vitamin D3 dan B12 mempengaruhi proses metabolisme protein pada mikroba kefir. Pada fase jam tersebut diduga merupakan fase pertumbuhan bakteri yang optimal dalam hal ini adalah terjadinya produksi beberapa komponen protein.

\section{pH}

Data pada Tabel 7 menunjukkan bahwa $\mathrm{pH}$ pada perlakuan jam fortifikasi tidak berbeda signifikan $(\mathrm{p}=0,800)$. Kondisi $\mathrm{pH}$ tersebut berada pada rentang produk kefir yang baik, kecuali pada penambahan frortifikan jam ke 24 , yang seharusnya berkisar pada 4.2-4.6. ${ }^{27} \mathrm{pH}$ sistem kefir sangat dipengaruhi oleh keberadaan bakteri asam laktat, semakin banyak bakteri asam laktat, maka $\mathrm{pH}$ produk menjadi semakin asam. ${ }^{32}$ Sedangkan khamir 
dalam system kefir akan mengubah laktosa menjadi alcohol dan mempengaruhi peningkatan $\mathrm{pH}$ pada kefir. $^{33}$

\section{SIMPULAN}

Berdasarkan kajian yang telah dilakukan terhadap fortifikasi vitamin B12 dan D3 pada kefir susu kambing, diketahui bahwa fortifikasi secara bersama vitamin D3 dan vitamin B12 pada kefir akan meningkatkan kadar vitamin D3 tetapi tidak pada vitamin B12. Vitamin D3 dan vitamin B12 dapat mempengaruhi metabolisme sistem kefir tetapi tidak ada kecenderungan untuk berinteraksi satu dengan yang lain. Hasil penelitian ini merekomendasikan untuk melakukan fortifikasi pada jam ke 12, dimana dimungkinkan adanya efek sinergistik antara vitamin D3 dalam kefir dan fortifikan serta mutu kefir yang masih baik berdasarkan hasil analisa protein, lemak, serat, $\mathrm{pH}$ dan viskositasnya.

\section{UCAPAN TERIMA KASIH}

Ucapan terimakasih penulis sampaikan kepada Hibah Penelitian RPP FK Universitas Diponegoro.

\section{DAFTAR PUSTAKA}

1. Chaitow $\mathrm{L}$ and Trenev N. Probiotics The Revolutionary 'Friendly Bacteria' Way ti Vital Health and Wellbeing. Thorsons paperback; 2002.

2. Usmiati S. Kefir, susu fermentasi dengan rasa menyegarkan. Warta Penelitian dan Pengembangan Pascapanen Pertanian, 2007; 29(2): 12-17.

3. Adeskon IA, Odetoyinho BB, Ekanola YA, Avenrenren RE, Fakorede S. Production of Nigerian nono using lactic starter cultures. Pakistan Journal of Nutrition. 2011;10(3):2037.

4. Devandra, C and Marca B. Goat Production in the Tropics. Slough: Commonwealth Agricultural Bureau ; 1983.

5. Fathir FN, Astawan M. Pembuatan yoghurt sinbiotik dari susu kambing peranakan etawa menggunakan kultur campuran bakteri asam laktat sebagai pangan fungsional pencegah diare. Institut Pertanian Bogor; Skripsi; 2010.

6. Vaclavic VA. Christian EW. Essentials of Food Science. New York: Springer; 2008.

7. Blakely $\mathbf{J}$ and Bade D. Ilmu Peternakan Edisi ke Empat. In: Srigandono B, editor. Yogyakarta: Gadjah Mada University Press; 1998. p. 351352.

8. Waldherr FW, Doll VM, Meissner D, Vogel R. Identification and characterization of a glucan- producing enzyme from Lactobacillus hilgardii TMW 1.828 involved in granule formation of water kefir. Food Microbiol. 2010; 27: 672-8.

9. Chen HC, Wang SY, Chen M. Microbiological study of lactic acid bacteria in kefir grains by culture-dependent and culture-independent methods. Food Microbiol. 2008;25:492-501.

10. El-Kholy AM, Osman M, Gouda A. Ghareeb WA. Fortification of yoghurt with iron. World Journal of Dairy \& Food Science, 2011;6(2):159-65.

11. Howell SL. The biosynthesis and secretion of insulin. In: Pickup JC editor. Text Book of Diabetes $2^{\text {nd }}$ ed. London; 1997. p. 1-14.

12. American Diabetes Association. Report of the Expert Committee on the Diagnosis and Classification of Diabetes Mellitus Clinical Practice Recommendations 2004. Diabetes Care. 2004. p. 27.

13. Garland CF, Garland FC, Gorham ED, Lipkin M, Newmark H, Mohr SB et al. The role of vitamin $\mathrm{D}$ in cancer prevention. Am J Public Heal. 2006;96(2):252-61.

14. Munger KL, Levin LI, Hollis BW, Howard NS . Serum 25-hydroxyvitamin D levels and risk of multiple sclerosis. JAMA. 2006;296(23):28328.

15. Forouhi NG, Luan J, Cooper A, Boucher BJ, Wareham NJ. Baseline serum 25hydroxyvitamin $\mathrm{D}$ is predictive of future glycemic status and insulin resistance: the Medical Research Council Ely Prospective Study 1990-2000. Diabetes. 2008;57(10):261925.

16. Wang TJ, Pencina MJ, Booth SL, Jacques PF, Ingelsson $\mathrm{E}$, Lanier $\mathrm{K}$ et al. Vitamin $\mathrm{D}$ deficiency and risk of cardiovascular disease. Circulation. 2008;57(10):2619-25.

17. Alm L. Effect of fermentation on milk fat of Swedish fermented milk products. J Dairy Sci. 1982;65:521-32.

18. Bouillon R. Vitamin D: from photosynthesis, metabolism, and action to clinical applications. In: Jameson JL, De Groot LJ, de Kretser DM et al, editor. Endocrinology: Adult and Pediatric. 7th ed. Philadelphia, PA: Elsevier Saunders; 2016.

19. Chernecky, CC and Berger BJ. Vitamin D (Cholecalciferol) - plasma or serum. In: Jameson JL, De Groot LJ, de Kretser DM et al, editor. Laboratory Tests and Diagnostic Procedures. Philadelphia, PA: Elsevier Saunders; 2013. p. 1182-3.

20. Kumar A and Kumar RG. To Develop a simple (UV-VIS) spectrometric method for the estimastion of multivitamin with special 
reference to capsules. Int $\mathrm{J}$ Pharmagenes. 2011;243-8.

21. Fauzyah F, Panunggal B, Afifah DN, Rustanti N, Anjani G. Microbiological characteristic and nutrition quality of goat milk kefir based on vitamin D3 fortification time. IOP Conf Ser Earth Environ Sci. 2018;116.

22. Forrest SA, Yada RY, Rousseau D. Interactions of Vitamin D3 with Bovine $\beta$-Lactoglobulin A and $\beta$-Casein. $\mathrm{J}$ Agric Food Chem. 2005;53:8003-9.

23. Mal R and Radiati L. Pengaruh lama penyimpanan pada suhu refrigerator terhadap nilai $\mathrm{pH}$, viskositas, total asam laktat dan profil protein terlarut kefir susu kambing. Universitas Brawijaya; 2013.

24. Beshkova DM, Simova ED, Simov ZI, Frengova GI, Spasov ZN. Pure cultures for making kefir. J Food Microbiol. 2002;19:53744.

25. Kneifel W. and Mayer H. Vitamin profiles of kefirs made from milks of different species. Int J Food Sci Technol. 1991;26(4):423-8.

26. Fang $H$, Kang $J$, Zhang $D$. Microbial production of vitamin B12: a review and future perspectives. Microb Cell Fact. 2017;16:15.

27. Bruinenberg PG. Smid EJ. Increased vitamin content in fermented milk product. Eur Pat Off. 2006.
28. Leite AMO, Leite DCA, Aguila EMD, Alvares TS, Peixoto RS, Miguel MAL et al. Microbiological and chemical characteristics of Brazilian kefir during fermentation and storage processes. Dairy Sci 4. 2011;96:4149-59.

29. Codex Alimentarius. Milk and milk produtcs. FAO dan WHO. 2011. p. 56-8.

30. Sawitri M. Pengaruh Konsentrasi Kefir Grains Terhadap Kualitas Kefir Laporan Penelitian Fakultas Peternakan. Universitas Brawijaya; 1996.

31. Mc Cleary BV, DeVries JW , Rader JI., Cohen G, Prosky L, Mugford DC. Champ M dan Okuma K. Collaborative study report: Determination of insoluble, soluble, and total dietary fiber (codex definition) by an enzymatic-gravimetric method and liquid chromatography. AACC Int Rep 2011. 2012;56:238-47.

32. Simova E, Beshkova D, Angelov A, Hristozova TS, Frengova G and Spasov G. Lactic acid bacteria and yeasts in kefir grains and kefir made from them. J Ind Microbiol Biotechnol. 2002;28:1-6.

33. Bulgari O, Caroli AM, Chessa S, Rizzi R and GC. Variation of vitamin D in cow's milk and interaction with $\beta$-lactoglobulin. J Mol. 2013;18:10122-31. 